\title{
La traducció automàtica en l'ensenyament de la traducció del català vers l'alemany: anàlisi dels resultats de les eines Google Translate i Bing Microsoft Translator
}

Christine Paasch-Kaiser

Universität Leipzig

christine.paasch-kaiser@uni-leipzig.de
Felix Hoberg

Universität Leipzig

felix.hoberg@uni-leipzig.de

Rebut: 13 de maig del 2020

Acceptat: 8 de setembre del 2020

\section{Resum}

El desenvolupament continu dels sistemes per a la traducció automàtica i la creixent acceptabilitat dels textos produïts mitjançant aquests sistemes fan qüestionar contundentment el paper del traductor humà. A més a més, l'ús de la traducció automàtica en la pràctica professional augmenta a causa de la demanda creixent de la clientela, per la qual cosa l'ensenyament també s'ha d'adaptar a les noves necessitats. No obstant això, encara hi ha deficiències serioses respecte als resultats d'aquestes traduccions automàtiques directes de la llengua catalana a l'alemanya. En l'article s'abordaran diferents aspectes problemàtics de les eines per a la traducció automàtica directa de la llengua catalana a l'alemanya actualment disponibles gratuïtament a Internet: Google Translate i Bing Microsoft Translator. Després de la descripció dels resultats obtinguts d'aquest estudi empíric basat en l'anàlisi profunda de diferents tipus de text, les troballes es comparen amb els resultats d'altres estudis sobre traducció automàtica en general i sobre la llengua alemanya en particular, a fi de millorar la integració d'eines de traducció automàtica a l'ensenyament de traducció del català a l'alemany.

\section{Paraules clau}

Alemany, Bing Microsoft Translator, català, ensenyament de traducció, formació de traductors, Google Translate, traducció automàtica

\begin{abstract}
The continuous development of machine translation systems and the increasing acceptability of texts produced through these systems forcefully question the role of the human translator. In addition, the use of machine translation in professional practice is increasing due to the growing demand from customers, so teaching must adapt to new needs. However, there are still serious shortcomings with regard to the results of automatic translations from Catalan into German. The paper addresses different problematic aspects of the tools for machine translation from Catalan to German that are currently available for free on the Internet: Google Translate and Bing Microsoft Translator. After describing the results obtained from this empirical study based on the in-depth analysis of different types of text, the findings are compared with the results of other studies on machine translation in general and on the German language in particular, in order to improve the integration of machine translation tools in the teaching of Catalan to German translation.
\end{abstract}

\section{Key words}

Bing Microsoft Translator, Catalan, German, Google Translate, machine translation, translation teaching, translator training 


\section{Introducció}

La digitalització i la tecnologització representen reptes importants per a la formació de traductors $^{1}$ i, per tant, també les carreres universitàries s'han d'adaptar als nous requisits tecnològics de la indústria de traducció. Aquesta remodelació és absolutament necessària tenint en compte que avui les eines digitals són imprescindibles per a traductors i intèrprets. No obstant això, manejar aquests programaris demana competències més profundes que l'ús quotidià d'aplicacions. La tecnologització de la indústria de traducció ja es pot observar des dels anys 1990, quan van baixar els preus dels ordinadors personals i simultàniament es van estendre les capacitats calculadores, aspectes que van crear noves demandes i perfils al mercat laboral (com mostra Schmitt (2019) respecte a l'àmbit de la traducció).

El desenvolupament continu dels sistemes (per intel-ligència artificial) i la creixent acceptabilitat dels textos produïts mitjançant aquests sistemes fan qüestionar contundentment el paper del traductor humà davant de la traducció automàtica (TA) (vegeu, p. ex., Himmelein 2019 i Holzki 2020 en mitjans alemanys). No obstant això, empreses com Lengoo indiquen que el traductor humà és important per a la millora del servei, ja que els proveïdors d'aquests serveis són molt conscients dels límits i dels errors de plataformes de TA com Google Translate. A diferència de Lengoo, aquesta empresa opta per l'oferta de TA en una gran gamma de llengües en lloc de millorar la qualitat de l'output, tot suposant que amb cada llengua es millora el sistema i per tant l'output (Holzki 2020).

L'ús de la TA és cada vegada més freqüent en la pràctica professional de les empreses i agències de traducció, i també dels traductors autònoms. Xifres actuals presentades en la conferència i fira anual tekom 2018 mostren que d'un 60\% al 70\% del volum total dels encàrrecs encomanats a agències de traducció alemanyes consisteixen en TA i postedició (PE). En el cas dels traductors autònoms, la xifra és més baixa perquè la TA demana capacitats digitals extensibles, encara que sistemes en línia com DeepL representen una alternativa més econòmica i accessible a tothom. No obstant això, el control i la protecció de les dades introduïdes en aquests serveis gratuïts, que els servidors guarden i utilitzen per a la millora dels serveis (cf. Holzki 2020), constitueixen un perill seriós — sobretot al treballar amb dades sensiblesamb què cal estar alerta.

Què significa això per a la formació de futurs traductors i, en particular, en l'àmbit de llengües menors (petita quantitat de parlants) com el català? Des del nostre punt de vista, cal integrar la TA, la PE i l'ensenyament de la utilització d'aquestes eines en la formació del traductor de qualsevol combinació de llengües. Pensem que el seu ús no s'ha d'integrar a l'ensenyament massa tard perquè l'estudiantat aprengui, des del principi, un maneig crític i controlat d'aquestes eines. ${ }^{2}$ El personal docent ha de capacitar l'estudiantat i transmetre-li els coneixements necessaris per a poder detectar problemes i errors que es produeixen usant la TA. Tot i que s'han dut a terme diversos estudis que analitzen els resultats de TA entre diverses llengües, encara no hi ha cap treball dedicat a la combinació que aquí estudiem i que podria fer servir el professorat de traducció del català a l'alemany. Per això, l'article tracta els reptes i problemes de l'ús de la TA amb la llengua catalana i l'alemanya.

Les possibilitats i les limitacions dels diferents sistemes (Google Translate ${ }^{3}$ i Bing Microsoft Translator ${ }^{4}$ ) usats en la formació universitària de traducció del català a l'alemany, resultats del

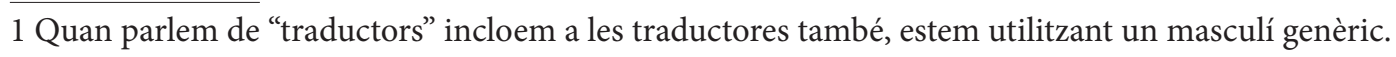

2 Entre els temes que necessàriament s'han de tractar es troba també l'ús de la TA per a la traducció de textos (altament) riscosos (en alemany (Hoch-)Risikotexte) amb dades sensibles (de persones, empreses, institucions públiques, etc.), sobretot quan s'usen eines accessibles gratuïtament que potser guardaran les dades per a estendre els recursos lingüístics naturals i millorar, d'aquesta manera, el seu servei.

3 Disponible a: $<$ https://translate.google.com/?hl=de\&tab=TT $>$.

4 Disponible a: <https://www.bing.com/translator $>$. 
projecte didàctic (vegeu apartat 3 ), seran l'objecte d'aquest article..$^{5}$ Sobretot ens ocuparà la qüestió del benefici i de la utilitat de la TA per a la traducció del català a l'alemany en general i per a l'estudiantat de grau i màster en particular. Això planteja, concretament, les preguntes següents:

(1) Quins problemes sorgeixen de la TA del català a l'alemany?

(2) Són aquests problemes els mateixos que aquells que també trobem en altres llengües?

(3) Quines dificultats s'han d'atribuir a la combinació de les llengües i quines al tipus de text?

Amb el nostre projecte i estudi pretenem contribuir a la necessitat identificada per Schmidthofer i Mair (2018) d'elaborar conceptes per a integrar l'ús de la TA de forma raonable i fructífera a la formació del traductor: "Los programas de formación de traductores deben integrar estas y otras herramientas que puedan complementar la traducción humana. Sin embargo, para diseñar actividades que incorporen este software, necesitamos datos y experiencia que puedan servir como punto de partida" (Schmidthofer i Mair 2018: 163-164).

En l'apartat 2 presentarem les eines de TA per a la combinació de llengües que estudiem, resumirem en l'apartat 3 el projecte didàctic d'integració de TA i PE en les classes de traducció a l'alemany i descriurem en l'apartat 4 els textos en què es basa el nostre projecte. Dedicarem l'apartat 5 a l'estudi dels problemes que sorgeixen de la TA del català a l'alemany per a resumir els nostres resultats i respondre a les preguntes (2) i (3) en l'apartat 6.

\section{Les eines de TA existents per a la combinació català-alemany}

En la pàgina web de la Generalitat de Catalunya (Gencat 2020a) es poden trobar tres plataformes en línia que ofereixen la traducció automàtica del català a l'alemany. Aquestes són Google Translate, Bing Microsoft Translator i Tradukka.

Google Translate es distingeix per ser un dels proveïdors de processament de llenguatge natural (PLN, en anglès Natural Language Processing) més coneguts, més ancorats en el mercat i més potents econòmicament. Ofereix 99 llengües, entre elles el català i l'alemany. Segons diuen, Google no busca la perfecció de les seves traduccions sinó que pretén proporcionar serveis per a llengües on es troben poques traduccions però textos originals suficients per generar correspondències (Holzki 2020).

Originalment, Bing és el nom del motor de recerca de Microsoft. En els darrers anys, Microsoft va estendre el departament de PLN. El rendiment del seu servei de traducció també va millorar, tot sumant un total de 63 llengües suportades. Microsoft fa ús de totes les dades introduïdes als seus productes (com Cortana, Bing, Office, Skype) per generar la base en què s'estan millorant les traduccions automàtiques. ${ }^{6}$ El servei de Tradukka, indicat per la Generalitat, es basa igualment en les dades de Bing Microsoft, fet pel qual no el tenim en compte de forma separada.

Un altre servei reconegut - encara que no apareix en la pàgina de la Generalitat - és la traducció assistida per ordinador (TAO, anglès CAT-Tool) en línia MateCat. ${ }^{7}$ Es tracta d'un servei que ofereix una part de l'entorn necessari per a la feina del traductor professional que li dona accés a diccionaris terminològics, traducció automàtica, memòries de traducció i, a més, li permet introduir-hi altres diccionaris, glossaris i corpus externs. ${ }^{8}$ Una particularitat de MateCat és el processament extensible de formats de dades ja que inclou els formats de text i d'imatge (p. ex. .pdf, .docx, .odt, .jpg). Encara que aquesta plataforma no genera dades

5 No es tracta d'un estudi que aborda les qüestions de la usabilitat de les eines de TA en general.

6 Vegeu també les informacions oferides per Microsoft (2016).

7 Disponible a <https://www.matecat.com/>.

8 Vegeu respecte d'aquests sistemes Zetzsche (2016: 38). 
sinó que accedeix a les fonts de Google i Microsoft, cal afegir que MateCat millora la qualitat de les traduccions automàtiques gràcies a les dades introduïdes pels usuaris, és a dir, que la TAO memoritza els segments traduïts per reutilitzar-los.

No tindrem en compte altres competidors, bé perquè no ofereixen la nostra combinació de llengües, com p. ex. Opentrad, Salt, Apertium, Softcatalà, DeepL o Lilt; o bé perquè s'han de pagar, com en el cas de Ta with you, Lengoo o Lilt. ${ }^{9}$ Tampoc considerarem el servei Skype translator, que rep les seves dades del Bing Microsoft Translator, perquè està inclòs en un sistema dialògic del xat que té com a primer objectiu un millor enteniment i no la traducció automàtica com a tal. ${ }^{10}$

Queda clar que l'oferta de TA per a la combinació català-alemany no gaudeix del mateix desenvolupament que altres combinacions, com p. ex. el castellà o l'anglès. Les eines per a la TA, que cal "entrenar" per aconseguir bones traduccions, demanen accés a amplis recursos lingüístics naturals no sempre disponibles. Aquells recursos procedeixen, en gran part, de la xarxa, on llengües com l'anglès, el castellà o el xinès s'utilitzen freqüentment per a la comunicació. ${ }^{11} \mathrm{Si}$ ens mirem les tecnologies disponibles i els projectes que es desenvolupen actualment, per exemple en el centre d'intel-ligència artificial Deutsches Forschungszentrum für Künstliche Intelligenz a Berlín, però també a escala global de la Unió Europea, ens adonem que hi ha tecnologies que ofereixen bons resultats per a les llengües de grans recursos com l'anglès o el castellà perquè hi ha corpus suficientment grans en els quals els programes es poden basar. A més a més, les traduccions d'una d'aquestes llengües a l'altra són d'una gran rellevància econòmica. Les llengües parlades per un petit nombre de parlants o les llengües minoritàries constitueixen un "problema", ja que tenen un pes polític o econòmic massa petit per a ser interessants (econòmicament) perquè grans empreses hi trobin lucre i, per això, millorin la seva oferta - encara que es podria remetre a les pràctiques de Google Translate descrites en Holzki (2020). Tenint en compte aquestes circumstàncies, l'equip del projecte de la UE CRACKER (cf. CRACKER 2020a i 2020b) parla d'una extinció lingüística digital (Digital Language Extinction in Europe) de llengües menors que es procura evitar mitjançant el projecte europeu QT21 - Quality Translation 21 (cf. QT21 2020). Per a llengües menors, com el català, manquen amb freqüència els actors interessats políticament i econòmicament en la creació de noves tecnologies lingüístiques potents per a combinacions lingüístiques diferents, com l'alemany, per no haver de passar per una altra llengua (en anglès, Relay-translation). No obstant això, en el cas del català hi ha un gran interès polític i s'estan invertint diners contínuament per crear i millorar la situació, el que mostren les informacions ofertes per la Plataforma per la Llengua, on s'indiquen diversos fets respecte a aquest tema (Plataforma 2019) i també els desenvolupaments prevists i actuals per part de la política lingüística catalana (GenCat 2020b i 2020c).

\section{Integració de la TA en la formació de traductors de català a l'IALT}

L'Institut de Lingüística Aplicada i Translatologia (IALT) de la Universitat de Leipzig (Alemanya $)^{12}$ ofereix els estudis de català (des del principi) a dintre de la carrera de Traducció,

9 Durant la revisió de l'article, vam conèixer un altre servidor que ofereix la TA del català a l'alemany, Yandex, disponible a <https://ranslate.yandex.com/>. Ho esmentem per la integritat de la informació, encara que no serà tractat en aquest article.

10 Actualment, Felix Hoberg està preparant una tesi doctoral a la Universitat de Leipzig, en la qual proposa un model per a analitzar el rendiment de l'Skype Translator, és a dir de la TA en viu, a base dels diàlegs escrits entre parlants d'alemany i català.

11 Respecte a l'ús del català en la xarxa, la Plataforma per la Llengua indica en un dels seus fullets en anglès: "Catalan is the 8th language by Internet penetration in the world. Catalan has an Internet penetration rate of 71.44, ahead of French, Italian, German, and Spanish. The penetration rate is the number of Internet users divided by the country's total population" (Plataforma 2019).

12 Més informació a <www.ialt.de> i <https://ialt.philol.uni-leipzig.de/institut/lektorate/katalanischlektorat/>. 
amb l'opció d'esdevenir traductor de català com a segona o tercera llengua (és a dir: llengües $\mathrm{B}$ o C). Aquesta universitat és l'única a tot Alemanya on s'ofereix la possibilitat de fer estudis de traducció (professional) amb el català. ${ }^{13} \mathrm{Al}$ semestre d'hivern 2019/20, en una assignatura de traducció del català cap a l'alemany, es va experimentar amb la TA de diferents tipus de text i es van aplicar diferents eines per a la TA d'aquesta combinació. Es tracta d'un projecte didàctic que porta el títol "Manuell, maschinell, digital - Co-teaching-Projektskizze für die Einbindung von digitalen e-learning-Elementen und maschineller Übersetzung in die Lehre des manuellen kulturbezogenen Übersetzens Katalanisch-Deutsch für B. A. Translation, M. A. Translatologie und M. A. Konferenzdolmetschen". El curs forma part de diferents mòduls de les carreres de grau i màster. Per això, es dirigeix tant a qui participa en un mòdul d'aprenentatge de català com a qui estudia el català dintre de la seva carrera de traducció (o interpretació).

Tenint en compte els nous requisits que demana el mercat laboral als traductors, la integració de TA i PE es fa, normalment, quan l'estudiantat ja té la base teòrica i les primeres experiències pràctiques de traducció. En el cas del català, el repte per al professorat és incloure estudiants de diferents nivells d'estudis, amb diferents coneixements previs, ja que poden començar a estudiar català en qualsevol moment de la seva carrera, i de les diferents titulacions (Grau en Traducció, Màster (no consecutiu) en Traductologia i Màster en Interpretació Simultània, així com dels estudis filològics o d'altres carreres no filològiques). A més, hi poden assistir estudiants d'altres països amb diferents coneixements d'alemany i català (per exemple, estudiants Erasmus). En aquests cursos de traducció, als quals s'assisteix a partir del tercer semestre de llengua catalana, s'ha de trobar un enfocament didàctic que, al mateix temps, permeti incloure tots els membres del grup (amb diferents competències en l'àmbit de la traducció) i sensibilitzar-los per a les possibilitats, els problemes i els límits de la TA (i PE) encara que mai no hagin (o encara no hagin) assistit a la introducció teòrica sobre tecnologies lingüístiques.

En el curs del semestre d'hivern vam treballar amb diferents tipus de text que tractaven diversos aspectes del tema de l'habitatge. A continuació presentarem, breument, els diferents tipus de textos que vam escollir, abans d'entrar en la descripció dels aspectes problemàtics de la TA observats amb Google Translate i Bing Microsoft Translator, així com el grup d'estudiants que hi va participar.

\section{La base de textos, els encàrrecs de traducció i el grup d'estudiants}

El semestre d'hivern 2019/20 es va constituir de 16 setmanes amb 12 sessions. ${ }^{14}$ En total vam treballar amb sis textos que tenien diferents longituds i graus de dificultat. Per assegurar-nos que el grup havia comprès els textos i disposava de les competències necessàries per detectar els punts febles o crítics de les TA, sempre de primer fèiem la traducció humana del text de sortida abans d'analitzar els resultats de Bing i Google.

Vam escollir quatre tipus de text:

1. Dos anuncis immobiliaris que procedien dels portals www.api.cat (Ref. 002334; accés: 14/10/2019, 182 paraules, en endavant API) i www.agenthia.com (Ref. 1002478; accés: 7/8/2019, 151 paraules, en endavant Agenthia).

13 A Alemanya, hi ha 20 universitats que tenen un lectorat del català finançat per l'Institut Ramon Llull (Institut Ramon Llull 2020) i que ofereixen classes de llengua catalana, entre les quals es troba la Universitat de Leipzig. La nostra recerca va mostrar que tampoc es pot estudiar traducció amb català en universitats suïsses o austríaques (agraïm a Mónica Máiquez Gómez la seva ajuda en aquestes recerques). A més a més, en la revista de l'Associació Germano-Catalana Zeitschrift für Katalanistik es publica, tots els anys, un llistat de tot el que hi ha de docència del català a les universitats de parla alemanya. Vegeu, per exemple, Blaschke (2018: 351-360).

14 En les quatre setmanes restants vam introduir el concepte del curs, vam assajar la prova final i repassar els seus resultats i vam fer la prova final. 
2. Dos textos periodístics, presos de www.vilaweb.cat ("Gentrificació i altres mites barcelonins" del 10/2/2017; accés: 15/8/2019, 1.198 paraules, del qual vam tractar dues parts de 356 paraules i 292 paraules, en endavant Vilaweb) i de www.arabalears.cat ("La prohibició del lloguer turístic als habitatges plurifamiliars a Palma arriba a 'The New York Times'” del 25/6/2018; accés: 15/8/2019, 462 paraules, en endavant ARABal).

3. Un cartell d'una associació de veïns per invitar a participar en la Comissió d'habitatge del Poblenou (https://www.elpoblenou.cat/index.php/comisio-dhabitatge; accés: 15/8/2019, "Grup d'acompanyament comissió d'habitatge del Poblenou"). Vam usar, en aquest cas concret, l'eina MateCat que intenta respectar el format del document pujat i a més permet treballar amb .pdf i .jpeg. Al tractar-se, d'una banda, d'una eina basada en la xarxa i, d'altra banda, d'una eina que recorda les correccions fetes per la persona usuària, cada ús millora els seus resultats. No obstant, com que vam traduir el cartell amb MateCat solament per introduir aquesta eina, en l'estudi no tindrem en compte els resultats de la seva TA.

4. Una pàgina web amb preguntes i respostes de la Generalitat de Catalunya sobre l'ús turístic d'habitatges: http://empresa.gencat.cat/ca/treb_departament/treb_preguntes_i_respostes/emo_turisme/emo_habitatges; accés: 5/1/2020, 15 preguntes, 1.206 paraules, de les quals ens vam limitar a les primeres 5 preguntes amb 369 paraules, en endavant HUT).

També havíem fixat els aspectes sintàctics i formals de major importància corresponents a cada text. Es tractava de xifres i unitats de mesura, puntuació, ús d'adjectius, construccions impersonals, conjuncions i estructura oracional respecte a tema i rema. Són temes que, en general, constitueixen problemes per a l'estudiantat de català i, sobretot, de traducció del català cap a l'alemany. En el cas dels anuncis immobiliaris hem d'admetre que no es tractava de textos originalment escrits en català sinó en castellà. Ens en vam adonar gràcies als errors que hi havia, però no vam trobar cap portal només en català amb aquest tipus d'anuncis.

Els encàrrecs del curs no variaven; el grup sempre havia de traduir els textos mantenint la seva funció (en alemany Funktionskonstanz) per als clients alemanys que no sabien català i que estaven interessats a llogar o comprar un apartament a Barcelona o a Palma de Mallorca, i que volien informar-se sobre les condicions i restriccions del lloguer turístic i els problemes de gentrificació. ${ }^{15}$

El grup d'estudiants que participava en aquest curs es componia d'onze estudiants, nou dones i dos homes. Quatre eren estudiants Erasmus, dos estudiaven romanística i els cinc restants procedien de les diferents carreres ofertes a l'Institut de Lingüística Aplicada i de Translatologia. El nivell de català dels estudiants de la Universitat de Leipzig era d'entre A2.2/B1.1 del Marc Europeu Comú de Referència per a les Llengües i B2, mentre que totes les estudiants Erasmus, que procedien de diferents regions dels Països Catalans, tenien el català com a L1; el seu nivell d'alemany variava entre B1.1 i B2/C1. Resumim aquestes dades en la taula 1 :

\begin{tabular}{|l|l|l|l|l|}
\hline Núm. & Carrera & Gènere & $\begin{array}{l}\text { Nivell de llengua } \\
\text { catalana }\end{array}$ & $\begin{array}{l}\text { Nivell de llengua } \\
\text { alemanya }\end{array}$ \\
\hline 1 & B. A. Romanistik & f & A2.2/B1.1 & L1 \\
\hline 2 & B. A. Romanistik & m & B2 & L1 \\
\hline 3 & B. A. Translatologie (C-Sprache) & m & B2 & L1 \\
\hline 4 & M A. Translatologie (C-Sprache) & f & A2.2/B1.1 & L1 \\
\hline
\end{tabular}

15 No tenim en compte exercicis que fan referència a altres encàrrecs possibles com la interpretació informal parafrasejada a l'alemany (en alemany Vom-Blatt-Übersetzen o Stehgreifübersetzung) o el resum de textos catalans en alemany que s'utilitzen com a tècnica a l'ensenyament del català a l'Institut de Lingüística Aplicada i Translatologia de Leipzig que descriuen Bernaus Griñó i Sinner (2016: 205-207). Vegeu a més Sinner i Wieland (2013), Sinner i Bahr (2015) i Sinner (2017) que ofereixen una descripció detallada respecte de l'aprenentatge del català a l'IALT i el paper de la mediació lingüística dins el seu ensenyament en aquesta institució, així com en l'ensenyament d'L2 en general. 


\begin{tabular}{|l|l|l|l|l|}
\hline 5 & M. A. Translatologie (C-Sprache) & f & A2.2/B1.1 & L1 \\
\hline 6 & M. A. Translatologie (C-Sprache) & f & A2.2/B1.1 & L1 \\
\hline 7 & $\begin{array}{l}\text { M. A. Konferenzdolmetschen } \\
\text { (C-Sprache) }\end{array}$ & f & B1.1 & L1 \\
\hline 8 & Erasmus & f & L1 & B1 \\
\hline 9 & Erasmus & f & L1 & B1 \\
\hline 10 & Erasmus & f & L1 & B1 \\
\hline 11 & Erasmus & f & L1 & B2/C1 \\
\hline
\end{tabular}

Taula 1: Participants del curs de traducció del català cap a l'alemany en el semestre d'hivern 19/20.

\section{Resultats de l'anàlisi de la TA feta amb Google Translate i Bing Microsoft Translator}

\subsection{Observacions generals}

En aquest apartat tractarem els aspectes problemàtics observats durant la preparació dels textos per a la TA i en les classes on vam comentar les TA amb el grup. Classificarem els nostres resultats en diferents categories que coincideixen amb les troballes d'altres estudis (vegeu la conclusió d'aquest article en 6). No obstant això, no adoptarem cap de les estructures proposades en els estudis anteriors perquè enfoquem el tema de la TA des d'una perspectiva didàctica. Seguim la nostra estructura perquè el nostre apropament al tema és inductiu, com ho és en el cas de l'estudiantat amb qui vam analitzar els textos. El nostre propòsit és subratllar quins són els reptes específics per a qui estudia el català quan s'utilitza la TA per a la combinació català-alemany, i no solament mostrar que vam descobrir els mateixos fenòmens o errors que s'havien detectat abans en altres estudis sobre altres combinacions lingüístiques, encara que en parlarem en l'apartat 6. Pretenem oferir una ajuda vàlida per al professorat i a l'estudiantat per al reconeixement i la descripció de fenòmens i errors que vam observar en les traduccions automàtiques del textos analitzats. Malgrat que solament enfocarem alguns aspectes determinats - ja que no es tracta d'un estudi exhaustiu - ens sembla fonamental afrontar, discutir i buscar solucions per als problemes i errors observats, ja que és molt important en la formació del futur traductor (i/o posteditor).

Des del punt de vista científic, la TA i la pre- i postedició representen àmbits fructífers avui en dia. Hi ha moltes publicacions i presentacions al respecte. ${ }^{16}$ Per fer-se una idea dels requisits tecnològics imprescindibles al llarg del curs, cal, abans de tot, considerar les definicions de la PE. Grizzo (2017) defineix molt bàsicament la postedició com la remodelació d'un text automàticament traduït. A més, distingeix entre la PE lleugera i completa, en què la diferència principal és la qualitat del producte. La PE lleugera només té com a objectiu redactar un text llegible, però no apte per ser publicat. Per contra, la PE completa ha de produir un text de qualitat superior i equivalent a la traducció feta per un humà. Elsen (2012: 16) entén la PE

16 S'han publicat diversos articles sobre la postedició des de les més diferents perspectives, entre ells, per esmentar-ne només alguns ja que el nostre propòsit no és fer un repàs bibliogràfic, trobem Bowker i Buitrago Ciro (2015), que examinaven la percepció dels usuaris pel que es refereix a traduccions humanes en comparació amb traduccions automàtiques (lleugerament i completament posteditades); Čulo i Nitzke (2016), que analitzaven la variació terminològica en traduccions humanes i automàtiques posteditades així com Čulo, Hansen-Schirra i Nitzke (2017) que es dedicaven a la variació terminològica en textos de llenguatge d'especialitat; Daems, De Clerc i Macken (2017) sobre la capacitat humana de distingir entre traducció i postedició i sobre un model per a la distinció automàtica de textos posteditats; Farrell (2018) en què s'estudien els marcadors de TA i es comparen els resultats de traduccions humanes fetes per estudiants amb aquells de traduccions automàtiques posteditades per estudiants pel que fa als efectes homogeneïtzants i normalitzants; Torral (2019) respecte a les característiques i la qualitat de textos posteditats o el més actual de Macken, Prou i Tezcan (2020) sobre la integració de PE en el flux de treball de la Direcció General de Traducció de la Unión Europea. 
com "un sistema de TA [que] produeix una traducció amb l'ajuda de grans quantitats de dades avaluades estadísticament i/o mitjançant el suport d'informacions i regles lingüístiques. És possible que aquesta pretraducció automàtica satisfaci els requisits qualitatius mínims i pot ser revisada (és a dir, reparada, posteditada) per millorar-la. D'altra banda, es rebutja aquesta pretraducció automàtica a causa dels seus defectes greus i es fa traduir de forma normal [per un traductor humà]" (Elsen 2012: 16; traducció nostra).

Tenint en compte aquesta graduació, al mateix temps esdevé necessari processar el text d'origen abans d'introduir-se en l'anomenada fase de preedició. Com que la majoria dels textos contenen una gamma de metainformacions formals, contextuals i cotextuals (salts de línia, imatges, referències, etc.), cal esborrar-les perquè la TA produeixi un resultat acceptable. Segons Elsen (2016: 12), les tasques d'un posteditor són les tres següents: (1) comprovar si la TA compleix els requisits qualitatius mínims i pot ser posteditada dintre d'un període raonable; (2) posteditar aquesta TA que s'ha qualificat com a utilitzable, i (3) en cas que s'hagi identificat un segment no utilitzable, fer la traducció d'aquest segment del text original.

En el primer número de la revista de l'associació de traductors austríacs de 2020 (UNIVERSITAS, Mitteilungsheft 1/20) es van resumir les diferents contribucions fetes en l'última conferència de l'associació nacional de traductors d'Alemanya BDÜ (Übersetzen und Dolmetschen 4.0: Neue Wege im digitalen Zeitalter), que es va celebrar el novembre del 2019 a Bonn. Grizzo (2019), com altres més recentment (vegeu les descripcions de les presentacions de Marciano i Canfora a UNIVERSITAS 2020), ha indicat que és molt important incloure el treball amb les eines de TA i PE en la fase de formació, ja que es tracta d'un àmbit en el perfil del traductor cada vegada més demanat. Constitueix, per consegüent, una tasca per a la qual els futurs traductors han d'estar preparats. La inclusió d'aquestes tecnologies en la formació és, per tant, essencial per obtenir les competències necessàries com ara competència lingüística, cultural, de traducció i de recerca.

Per a un millor maneig, la Translation Automation User Society (TAUS) ha publicat una guia (cf. Massardo et al. 2016) amb recomanacions sobre com manejar el procés del conjunt de TA i pre- i postedició (TAPE). Els diferents aspectes de la guia van més enllà del nucli de la TAPE. Fins i tot consideren quin personal posteditor se n'hauria d'encarregar en una agència professional, quin nivell de qualitat s'exigeix $\mathrm{i}$, finalment, quines fonts respecte a les TAO es requereixen (Massardo et al. 2016: 6). Entre els punts directament relacionats amb la TAPE, s'esmenten l'atenció; la preparació adequada, neta i estructurada del sistema de TAPE; la preedició ortogràfica, sintàctica i formal; l'administració de terminologia; l'avaluació dels resultats bruts de la TA per poder fer una oferta adequada als clients en qüestió i la retroacció al posteditor (Massardo et al. 2016: 15). En la conferència del BDÜ a Bonn, enfocada també a la TA i la pre- i la postedició, entre altres, Schmitt va presentar un estudi on comparava les eines Google Translate i DeepL per a la traducció de l'alemany cap a l'anglès. Va arribar a les conclusions que, en general, no s'havia de considerar la capacitat de l'eina en casos de paraules aillades o proposicions sense context que constitueixen problemes també als traductors humans. No obstant, va mostrar que hi ha grans diferències entre els resultats de les eines respecte als tipus de textos (millor amb textos àmpliament repartits i accessibles per al públic com manuals, però també en el cas de textos amb un alt nivell professional replets de terminologia es va arribar a resultats acceptables encara que no hi havia constància terminològica total). Els problemes els constitueixen, d'altra banda, els textos defectius que s'han de preeditar per obtenir bons resultats que no demanin una àmplia postedició. Aquest també va ser el tema de la presentació de Bickel, qui va esmentar els aspectes que haurien de preeditar-se per a una millora de la qualitat de les TA, com per exemple salts de línia al mig d'una oració, dites, unitats fraseològiques, enumeracions (amb oracions trencades), abreviacions, noms propis, verbs impersonals, aspectes dialectals o inconsistències terminològiques (SV/ UNIVERSITAS 2020: 16-17). També ha d'esmentar-se la publicació de Schmitt (2019), en la 
qual discuteix la situació actual del mercat laboral i les seves exigències als traductors, la relació entre TA i traducció humana, i com ha de canviar la formació de traductors a causa dels canvis que experimenta l'ecosistema de traducció per les "noves" tecnologies assequibles. ${ }^{17}$

En general es pot constatar que, en el nostre estudi, depenia molt del text si les eines van produir resultats satisfactoris o no. Els i les nostres estudiants comentaven que a primera vista algunes TA semblaven acceptables, però en analitzar-les amb més profunditat vam descobrir una sèrie d'aspectes on les eines no van satisfer les nostres exigències. No es tracta d'un estudi quantitatiu, és a dir, no presentarem nombres d'ocurrències de cada fenomen descrit. Tenint en compte que l'espai és limitat, no oferirem més d'un exemple de cada cas i no n'oferirem cap en aquells casos on una explicació no sembla necessària perquè se sobreentenen. No comentarem problemes formals com el desconeixement dels formats de titulars periodístics principals o secundaris ja que és conegut que els formats es perden en introduir el text en les eines de TA. Subratllarem els aspectes en qüestió; tenint en compte la configuració d'aquest estudi no sempre abordarem totes les possibles solucions que es podrien trobar ni tampoc tots els errors que hi ha en un sol exemple ja que no es tracta d'un estudi exhaustiu.

Els resultats d'aquest estudi procedeixen de la col-laboració amb l'estudiantat del nostre curs. Havien traduit els textos esmentats prèviament de forma manual. D'aquesta forma es van adonar de les dificultats formals, estilístiques, gramaticals, lèxiques i terminològiques que hi havia. En les traduccions humanes intentaven trobar bones solucions. ${ }^{18}$ En un segon pas, vam fer analitzar les TA de les dues eines Google Translate (d'ara endavant, GT) i Bing Microsoft Translator (d'ara endavant, BT) a casa (cada dues setmanes, dos alumnes preparaven les dues TA, una cadascú) i comparar els resultats amb les seves traduccions humanes. A la classe vam discutir les seves troballes. Així doncs, tots els casos que presentarem en els següents apartats van ser tractats en el curs del semestre d'hivern 2019/20 juntament amb els i les nostres estudiants. ${ }^{19}$

\subsection{Aspectes formals i estilístics}

En les diferents traduccions automàtiques en alemany, però sobretot en les dels anuncis immobiliaris, van mostrar-se mesures errònies. Es tracta, de tres problemes: a) la falta de l'espai de no separació entre el nombre i les mesures, la unitat monetària o el símbol de percentatge com en els exemples (1), (2) i (3), b) l'ús de mesures (errònies) angleses com en (4), i c) l'ús d'una majúscula i falta de l'elevació del quadrat com en (1), (2) i (5): ${ }^{20}$
(1) $110 \mathrm{~m} 2$ (API, BT, GT)
$\rightarrow 110 \mathrm{~m}^{2}$
(2) $€ 12 / \underline{m} 2$ (API, BT)
$\rightarrow 12 € / \mathrm{m}^{2}$
(3) $40 \underline{\%}$ (ARABal, BT, GT)
$\rightarrow 40 \%$
(4) $110 \underline{\mathrm{ft} 2}$ (API, BT)
$\rightarrow 100 \mathrm{~m}^{2}$

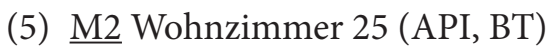
$\rightarrow \underline{\mathrm{m}^{2}}$ Wohnzimmer: $25 \mathrm{~m}^{2}$

Aquests errors no són constants, $\mathrm{i}$ hem de tenir en compte que també trobem variants correctes com en (6) i (7):

17 Es tracta d'idees que va presentar en la ponència inaugural del congrés LICTRA X. Internationaler Kongress zu Grundfragen der Translatologie. Translation 4.0 - Translation im digitalen Zeitalter, celebrat a Leipzig el 2017, un congrés que va enfocar la penetració de noves tecnologies - i les seves possibilitats i perills- en l'àmbit de la traducció i la interpretació (cf. Sinner / Paasch-Kaiser / Härtel 2020a i 2020b).

18 S'ha de tenir en compte que a la classe sempre intentem trobar la millor solució, ja que pensem que el context educatiu és el lloc on encara hi ha temps per reflexionar i discutir sense pressió de trobar-la immediatament, circumstància que més tard en la feina diària no hi ha per les demandes laborals.

19 Agraïm al conjunt dels nostres estudiants, col-legues i practicants pel seu interès i la seva cooperació en el projecte.

20 Vegeu al respecte, per exemple, la norma DIN 5008 (DIN 2020) o Duden (2020). 
(6) Das $\underline{98 \mathrm{~m}^{2}}$ große Neubaugeschoss ... (Agenthia, GT)

(7) ... 20 Minuten zu Fuß ... (API, BT)

Un error que es va repetir en moltes TA és l'ús de les cometes angleses (o catalanes) en lloc de les alemanyes („...“ “i sense espai abans del que tanca la citació, etc.) com en (8):21

(8) Maria Lindmäe, Professorin für Humangeographie an der Universität Pompeu Fabra, definiert dieses Phänomen als "die Erhöhung des Wertes des Kapitals, die Ergebnis der Ausweisung einer geringeren Kaufkraft." (Vilaweb, GT)

També s'observen errors ortogràfics i de puntuació, entre ells transcripcions incorrectes (9) o majúscules en lloc de minúscules a dintre de l'oració (10):

(9) cat. Fantàstic àtic excusivo [sic] en el mateix cor de l'Eix Macià de Sabadell... (API)

al. Fantastisches Penthouse im Herzen des Eix Macié in Sabadell ... (BT)

(10) cat. "Juntament amb la tendència de tenir menys fills, el retard en el matrimoni i una creixent taxa de divorci, els compradors i inquilins més joves estan canviant el somni dels seus pares per un de nou definit més en termes urbans que suburbans". (Vilaweb)

al. "Neben der Tendenz, weniger Kinder zu haben, Aufgrund der Verzögerung der Eheschließung und der zunehmenden Scheidungsrate ändern Käufer und jüngere Mieter den Traum ihrer Eltern, einen neuen zu finden, der eher in städtischen als in vorstädtischen Gebieten definiert wird. " (GT)

al. $\quad$ Neben der Tendenz, weniger Kinder zu bekommen, Eine wachsende Scheidungsrate, die jüngsten Käufer und Mieter ändern ihre Eltern 'Traum für einen neuen, der mehr in städtischen Begriffen definiert ist als Vorstadt ". (BT)

D'altra banda, ens va sorprendre l'ús de l'anglès en lloc de l'alemany (11):22

(11) cat. FINCAMPS PRESENTA (API)

al. FINCAMPS PRESENTS (BT) vs.

al. FINCAMPS PRÄSENTIERT (GT)

L'últim aspecte que volem mencionar en aquest apartat és el desconeixement de titulars per part de les eines (12). Es tracta d'un fet que vam observar únicament en un text on el Bing Microsoft Translator va reconèixer l'enllaç ${ }^{23}$ que estava integrat en el text, així com les lletres majúscules característiques dels títols anglesos. Per tant, va reconèixer, també, que no era necessari traduir l'oració en anglès per ésser el títol d'un llibre citat. Malgrat això, no es va formatar el títol de cap forma (p. ex. cometes, lletra itàlica). Google Translate, no obstant, va traduir aquest títol, fet que va distorsionar el sentit de l'oració, ja que deia que el geògraf escocès Neil Smith es trobava en el nou límit de la ciutat:

(12) cat. A La nueva frontera urbana, el geògraf escocès Neil Smith, catedràtic de la City University New York apuntava als canvis de l'estil de vida de la gent com una de les causes de la gentrificació ... (Vilaweb)

al. In The New Urban Frontier beschrieb der schottische Geograf Neil Smith, Professor an der City University New York, Veränderungen im Lebensstil der Menschen als eine der Ursachen für die Gentrifizierung ... (BT)

21 No hi ha cap sistematicitat ni en la mateixa eina. És a dir, es troben també casos en què apareixen les cometes correctes (ARABal traducció de GT) i altres en què no es reprodueixen les cometes (cf. Vilaweb traducció de GT).

22 Oferim un altre exemple (23) a l'apartat 5.5.

23 L'enllaç apareixia sota: <https://www.amazon.es/Nueva-Frontera-Urbana-Revanchista-Gentrificación/ $\mathrm{dp} / 8496453758>$. 
al. $\quad$ An der neuen Stadtgrenze wies der schottische Geograf Neil Smith, Professor an der City University New York, auf Veränderungen im Lebensstil der Menschen als eine der Ursachen für die Gentrifizierung hin ... (GT)

\subsection{Aspectes gramaticals: nivell morfològic, sintàctic i textual/estructural}

Es troben errors de cas, de gènere i de nombre en tots els diferents tipus de text. En l'exemple següent (13), mostrarem l'ús incorrecte del cas datiu que comporta l'ús gramatical inapropiat del nombre del lexema Einzelzimmer 'habitació individual', cas gramatical que demana el verb alemany bestehen aus 'consistir en'. El lexema ha de portar una -n perquè es tracta de $z w e i$ 'dues' habitacions individuals. Això també és vàlid per al lexema Bäder 'banys', perquè n'hi ha dos:

(13) cat. Pis dobra [sic] nova de $98 \mathrm{~m}^{2}$, consta de [sic] duna [sic] habitació doble i dues

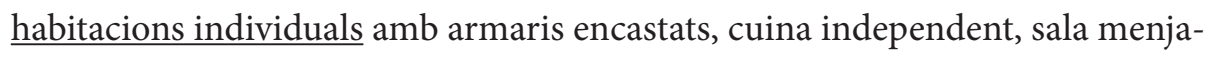
dor, dos banys complerts [sic] i rentador. (Agenthia)

al. Neue Wohnung von $98 \mathrm{~m} 2$, besteht aus Doppelzimmer und zwei EinzelzimmerØ

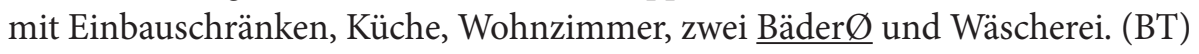

A (14) veiem un exemple que ens mostra que l'eina no distingeix correctament les designacions d'ocupació professional, encara que hi hagi, a més, el nom femení Maria, que confirma el sexe de la persona en qüestió. Com mostra aquest cas, l'eina no pren en compte el context lingüístic directe, malgrat que sigui un incís explicatiu en la mateixa oració. No vam trobar altres casos d'aquest error en els textos analitzats, però no sembla ser un fenomen poc freqüent ja que hi havia bastants altres exemples d'ús erroni del gènere gramatical.

(14) cat. Per la seva part, la presidenta de la Federació Empresarial Hotelera de Mallorca, María Frontera, ... (ARABal)

al. Der Präsident der Mallorca Hotel Business Federation, Maria Frontera ...

Vam constatar que l'eina no va reconèixer algunes perífrasis verbals, i per això va donar una TA mancada de sentit en alemany perquè separa els elements de la perífrasi verbal i els tracta com si fossin dos verbs individuals, començant una nova estructura sintàctica. És el cas de l'exemple (15), on en lloc de traduir la perífrasi verbal negada no para de comentar-se ... 'nicht aufhören ... zu kommentieren' en la TA de GT es va invertir el sentit a ... wurde ... nicht erwähnt 'no es va comentar', ometent la perífrasi verbal parar de. En el cas de la TA de BT passa el mateix si bé allí trobem, a més, una estructura sintàctica defectuosa en aquest context ist es nicht zu erwähnen que es tradueix literalment 'és això no de comentar', sense que quedi clar a què es refereix el pronom alemany es. És a dir, trobem una estructura impersonal que es podria considerar còpia (calc sintàctic) de l'estructura impersonal del català amb -se, però mal formulada ja que en alemany s'hauria d'usar la forma passiva (al. Vorgangspassiv) de l'auxiliar alemany werden que és wurde:

(15) cat. De fet, a l'assemblea del barri no para de comentar-se la suposada compra de la finca del carrer Doctor Trueta 234 per part d'una promotora "per a vendre els 10 pisos d'uns $70 \mathrm{~m} 2$ per 300.000-360.000€”. (Vilaweb)

al. Tatsächlich wurde bei der Versammlung des Stadtviertels der angebliche Kauf des Anwesens in der Calle Doctor Trueta 234 durch einen Promoter nicht erwähnt, "um die 10 Stockwerke von etwa $70 \mathrm{~m}^{2}$ für 300.000 bis $360.000 € \mathrm{zu}$ verkaufen". (GT) 
al. In der Tat, in der Versammlung der Nachbarschaft ist es nicht zu erwähnen, die angebliche Kauf der Farm von Doctor Trueta 234 auf Seiten eines Promoters "die 10 Wohnungen von etwa 70m2 zu 300.000-360.000 €zu verkaufen". (BT)

Respecte a la categoria dels verbs, observem que la TA no arriba sempre a traduir de forma adequada oracions que en alemany demanen un verb modal. Mentre l'original català en (16) emfatitza la recomanació (no obligació) de legalitzar l'habitatge d'ús turístic, la TA a l'alemany utilitza verbs modals diferents.

(16) cat. Per què convé legalitzar l'habitatge d'ús turístic? (HUT)

al. Warum muss das Wohneigentum legalisiert werden? (BT)

al. Warum sollten Sie ihr Zuhause für touristennahe Nutzung legalisieren? (GT)

La traducció de BT amb muss 'ha de' representa la recomanació que es basa en lleis, normes o principis generals com un acte obligatori; GT, d'altra banda, tria el verb sollen 'hauria de', que en aquest domini es considera el verb modal adequat perquè pressuposa una font extrasubjectiva de modalitat (cf. Duden 2009: \$820). El fet que el català utilitza haver de tant per expressar el valor del sollen com de müssen, encara que amb diferents modes del verb explica una part de la complexitat del tema i també és un repte per a molts i moltes estudiants d'alemany.

L'exemple (17) de BT és un exemple on trobem molts aspectes no satisfactoris, entre ells la traducció inapropiada de lexemes polisèmics o ambigus, l'omissió de paraules o la incongruència sintàctica comentada. No podem comentar tots els errors que s'amaguen en aquest exemple, per tant, ens limitem als aspectes gramaticals. En (17) són problemes a nivell sintàctic, en concret, l'ordre de les paraules que predomina sobre tots els altres errors:

(17) cat. Miralles assegura que els polítics s'han doblegat a lobby dels hotelers: "Prohibir Airbnb no farà res per resoldre la crisi d'habitatges, però aturarà la democratització d'un sector turístic que ha estat sempre controlat per uns pocs oligarques hotelers", afirma. (ARABal)

al. Miralles sagt, dass die Politiker in der Hotellobby verdoppelt haben: „Airbnb nichts tun Verbieten die Immobilienkrise, sondern stoppen die Demokratisierung des Tourismus zu lösen hat immer ein paar Oligarchen Hotel kontrolliert worden", sagt. (GT)

al. Miralles sagt, dass sich die Politiker in der Hotelier-Lobby verdoppelt haben: "Ein Verbot der Airbnb wird nichts zur Lösung der Wohnungskrise beitragen, sondern würde die Demokratisierung eines Tourismussektors stoppen, der seit jeher von einigen Hotelier-Oligarchen kontrolliert wird", sagt er. (BT)

Aquest tipus d'error es presenta amb molta freqüència quan es tracta d'estructures oracionals complexes amb proposicions incidents, citacions marcades formalment amb cometes o complements composats de diversos elements que les eines reprodueixen només parcialment sense "comprendre" el seu contingut o la connexió entre les seves proposicions (cf. al respecte Łopuszańska 2019: 154, Popović 2018: 247) ${ }^{24}$. En (17), a més del lèxic, és sobretot l'ordre totalment invertit de les paraules de la citació que causa la inintel-ligibilitat de tota la cita. L'eina no reconeix el subjecte de les oracions principals no farà res i aturarà la democratització que és l'oració subordinada substantiva d'infinitiu Prohibir Airbnb, un tipus de proposició que en alemany se sol expressar amb un Infinitiv mit zu (Airbnb zu verbieten, cf. Duden 2009: \$1650). En canvi, l'eina identifica el nom Airbnb com a subjecte i el separa de l'infinitiu Verbieten 'prohibir' que l'eina, per tant, reconeix com a "independent" i allunya del

24 Per a estudis similars a l'entorn de la TA estadística vegeu Farrús et al. (2009: 53-54) i Farrús et al. (2010: 170-171). 
nom. Respecte a l'estructura impersonal no farà res, en alemany s'expressa amb passiu wird + inf. D'altra banda, l'auxiliar alemany hat (que s'utilitza per a la formació del temps verbal Perfekt) s'utilitza incorrectament, ja que els verbs catalans apareixen en futur i no en passat. És a dir, hauria d'aparèixer la forma wird. Tampoc reconeix l'oració relativa especificativa que complementa la frase nominal sector turístic que la precedeix. L'últim comentari afecta l'ús d'un verb conjugat després de la citació sense pronom personal o repetició del nom (Miralles). Aquest element és necessari en alemany, mentre que en català, com a llengua de subjecte nul o elidit no cal repetir-lo.

Que les oracions de relatiu amb antecedent posen problemes a la TA es va mostrar des del primer text on la traducció va portar a una interpretació contrària al sentit de l'oració del text de partida (18). En lloc de del que és responsable... van traduir que és responsable per...:

(18) cat. Agenthia: La comunicació enviada quedarà incorporada a un fitxer del que és responsable AGENCIA D'EDIFICIS I SOLARS AGENTIA, S.L. (agenthia)

al. Die gesendete Mitteilung wird in eine Datei integriert, die für AGENCIA de EDIFICES I SOLAR AGENTIA, S.L. verantwortlich ist. (BT)

al. Die gesendete Mitteilung wird in eine Datei aufgenommen, die für die AGENCIA DE EDIFICIS I SOLARS AGENTIA, S.L., verantwortlich ist. (GT)

Una altra construcció que causava problemes a les eines era el gerundi de construcció no personal, com comunicant-ho a l'exemple (19), pel qual s'ha de trobar una alternativa en alemany que expressi el seu valor. Com que es tracta d'una construcció que també causa problemes als estudiants en la traducció manual, és molt important abordar-la detingudament. Cap de les dues eines va traduir el gerundi comunicant. Per més que en la TA de GT sembla haver-hi un verb, Senden 'enviar', aquest està relacionat únicament amb l'enviament d'un correu en la traducció alemanya de GT i no amb les diferents opcions de comunicació ofertes. En ambdues variants fa falta un verb d'acció com tun o machen (schriftlich tun) per completar l'acció.

(19) cat. Agenthia: En qualsevol moment vostè podrà exercir els drets d'accés, rectificació, oposició i, si s'escau, cancel-lació, comunicant-ho per escrit, tot indicant les seves dades personals a Avinguda Jaume I, 74 17001, Girona o mitjançant l'enviament d'un correu electrònic a info@agenthia.comAgenthia (agenthia)

al. Sie können jederzeit Ihre Rechte auf Zugang, Berichtigung, Widerspruch und gegebenenfalls Löschung ausüben, indem Sie es schriftlich Ø unter Angabe Ihrer personenbezogenen Daten in Avinguda Jaume I, 74 17001, Girona oder per E-Mail an info@agenthia.com (BT)

al. Sie können jederzeit von Ihrem Recht auf Auskunft, Berichtigung, Widerspruch und gegebenenfalls Löschung Gebrauch machen, indem Sie dies schriftlich $\underline{\varnothing}$ unter Angabe Ihrer persönlichen Daten in der Avenida Jaume I, 74 17001, Girona oder von 1 Senden Sie eine E-Mail an info@agenthia.com Agenthia (GT)

\subsection{Aspectes terminològics i lèxics}

Respecte a les inconsistències lèxiques, ambdós serveis de TA, Google i Bing, tenen problemes evidents amb paraules o entitats centrals dels textos introduits. El que és interessant és que al traduir la TA altera la construcció original catalana en cada ocasió que sorgeix en el text de partida. Com es pot veure en els exemples (20) i (21), els originals lloguers turístics i l'habitatge d'ús turístic són representats per expressions diferents:

(20)

cat. lloguer turístic (HUT)

1 al. touristische Miete (BT)

2 al Touristenvermietung (BT) 
3 al. Vermietung von Touristenunterkünften (GT)

4 al. touristische Vermietung (GT)

(21)

cat. habitatges d'ús turístic / habitatge d'ús turístic (HUT)

5. al. Wohnhaus für Touristen (BT)

6. al. Häuser für touristische Nutzung (BT)

7. al. Unterkunft für touristennahe Nutzung (BT)

8. al. Wohnungen zur touristischen Nutzung (GT)

9. al. Touristisch genutzter Wohnraum (GT)

10. al. touristisch genutzte Häuser (GT)

En ambdós casos, la variació es repeteix durant tot el text. El més problemàtic és que no totes les expressions utilitzades representen els conceptes de lloguer turístic o habitatge d'ús turístic en alemany. Lloguer turístic (20) convé millor ser entès com l'acte d'oferir en lloguer un habitatge a turistes en una àrea intensament freqüentada. La composició Touristenvermietung, al revés, significa lloguer de turistes en el sentit estricte literal, és a dir, que es lloguen turistes com bicicletes.

L'exemple d'habitatges d'ús turístic (21), a més, presenta un altre problema: definir quin concepte alemany quadra millor amb la idea d'habitatge en català. En les TA trobem tant Wohnung, com Wohnraum 'espai per a viure' com simplement Haus 'casa' o Wohnhaus 'casa o immoble/edifici per a viure' i Unterkunft, que també es pot dir, però en alemany inclou tot tipus d'allotjament: des del sofà (en el cas del couch surfing) fins a l'hotel de cinc estrelles.

També és evident que els resultats de la TA des del punt de vista terminològic són inconsistents i a vegades incorrectes. En tots els textos que vam tractar durant el semestre es troben aquestes inconsistències. A tall d'exemple d'això incloem el cas de (22).

(22) cat. ... tot i que la seva comercialització i gestió es pot encomanar a una tercera persona (intermediari o gestor). (HUT)

al. $\quad$... obwohl seine Vermarktung und Verwaltung einer dritten Person (Vermittler oder Geschäftsführer) übertragen werden kann. (GT)

al. $\quad$... obwohl ihre Kommerzialisierung und Verwaltung einer dritten Person (Zwischenhändler oder Manager) anvertraut werden kann. (BT)

Terminològicament, com en el cas dels exemples (20) i (21), la TA proposa solucions diferents per als mateixos conceptes per a intermediari o gestor (22). A més, en el cas de l'exemple (22), les solucions proposades tenen un valor semàntic que no quadra completament amb intermediari o gestor. Les paraules catalanes són polisèmiques. Un Zwischenhändler és una persona que intervé en una transacció comercial, un 'mediador' o 'mitjancer'. No és una persona que, com consta a l'original, té la facultat legal (per encàrrec) per actuar en lloc d'una altra persona. Tampoc es tracta exactament d'un Vermittler, que només es posa en contacte amb persones o serveis. Més adequat seria, en aquest context, el concepte de Bevollmächtigter, que equival a 'apoderat' en català. El mateix cal dir per a gestor, traduït per Geschäftsführer 'gerent d'una societat, una associació, etc.' (GT) i Manager 'mànager d'una multinacional, etc.' (BT). No són les accepcions adequades triades per les eines, ja que en aquest context es tracta més aviat d'una "[p] ersona que professionalment es dedica, per encàrrec d'un tercer, a resoldre i a activar afers que no requereixen la compareixença de l'interessat" (DicCat 2020, s. v. gestor).

Tenint en compte que el context d'aquest article és un curs de traducció amb l'objectiu de tractar problemes relacionats amb la competència cultural necessària dels futurs traductors, les inconsistències terminològiques no representen els problemes d'ordre primari. Però al mateix temps, és imprescindible que l'estudiantat aprengui quan —en quins tipus de text, per a quina ocasió, 
per a quin encàrrec, etc. - és absolutament imprescindible fer ús d'una terminologia consistent. La precisió terminològica és important, per exemple, per a la traducció de reglaments, manuals tècnics o prospectes que acompanyen un medicament. Per això, l'observació de les inconsistències terminològiques resultava moltes vegades en discussions llargues durant el curs.

Un problema semblant constitueix l'ús erroni de lexemes de la llengua general. Un cas que ja hem indicat és el de l'exemple (17). Allà vam detectar la traducció de doblegar-se 'sich beugen' per verdopplen 'duplicar-se' en GT, però també en BT. Un altre cas en el mateix exemple és la traducció del verb polisèmic aturar per stoppen (GT), encara que en aquest context significa verhindern 'impedir', resultats que, a part dels altres errors descrits, donen un sentit distorsionat a la traducció.

L'últim aspecte que incloem, breument, en aquest apartat és la supressió de paraules. No és un problema desconegut (cf. Łopuszańska 2019: 154) el qual vam observar en les traduccions fetes per ambdós serveis de TA, Google i Bing, un fet que hem descrit en el cas de (19) i sobre el qual cal cridar la atenció de l'estudiantat.

\subsection{Traducció de topònims}

Respecte a alguns topònims vam observar una cosa interessant, però no desconeguda pels usuaris d'eines de TA. Es tracta de la traducció de topònims que, com els noms propis, se solen classificar com paraules poc freqüents que poden causar problemes a l'hora de traduir-les (cf. Łopuszańska 2019: 154 i Wu et al. 2016: 2). Vam observar aquest problema en les traduccions dels anuncis immobiliaris on, en el cas de (23), es tracta del titular d'un anunci. Cap de les dues eines va reconèixer la designació d'una part del barri Eixample Sud de Girona que es diu Químics (vegeu també 5.6 respecte de conceptes desconeguts). Cap eina va fer una assignació correcta de les paraules del titular encara que van mantenir l'ordre de les paraules. A més, GT les va traduir totes a l'anglès en lloc de fer-ho a l'alemany i BT va fer una barreja entre l'alemany Süd i l'anglès Chemics.

(23) cat. GIRONA EIXAMPLE SUD QUÍMICS (Agenthia)

al. GIRONA EIXAMPLE SÜDCHEMICS (BT)

al. GIRONA EIXAMPLE SOUTH CHEMICALS (GT)

\subsection{Traducció de terminologia específica: la manca d'informació addicional}

Com que a l'entorn de la traducció es tracten múltiples vegades conceptes extralingüístics que només existeixen de tal forma en l'espai cultural de partida (vegeu p. ex. Markstein 1999 o Kupsch-Losereit 2009), cal trobar una manera per fer comprendre al receptor de la traducció aquest concepte inexistent en la llengua i cultura d'arribada. Aquests elements específics d'una cultura poden formar part de la religió, de la política, de les institucions respectives, les convencions o col-locacions - tots lingüístics o extralingüístics - i més. En el cas de la TA, és necessari identificar i manejar conceptes de la cultura (o llengua) de partida per poder afegir una explicació adequada en la llengua d'arribada en el pas de postedició i segons l'encàrrec. La qüestió és com identificar i manejar-ho en el pas de la postedició. En els exemples (9) i (13) hem observat que la TA negligeix elements representatius de la cultura de partida. En (9), falta l'explicació del concepte de Eix Macià que sembla ésser un lloc a Sabadell, encara que designi diferents coses (avinguda i centre de serveis) alhora i resta, per tant, poc transparent per al lector alemany. Però la part dolenta és que no proporciona informació addicional sobre què és exactament. En un altre extracte d'un anunci d'habitatge (13) hi ha un problema d'especificitat cultural que en aquest cas consisteix en les idees o convencions diferents per designar les habitacions entre l'espai cultural català i alemany; es tracta de la traducció de habitació individual per 'Einzelzimmer' i de habitació doble per 'Doppelzimmer'. Des del nostre punt de vista (hi incloem el del nostre estudiantat) la traducció de habitació individual 
per 'Einzelzimmer' no és adequat en aquest context. Sembla ser una convenció dels anuncis immobiliaris alemanys ${ }^{25}$ indicar la grandària de les habitacions i sales perquè en una habitació petita es pot posar un llit de dos pisos, llavors ja no és un Einzelzimmer. Segons el Duden (2020) aquest lexema sol utilitzar-se només en el context de l'hoteleria o de l'hospital. En el corpus German Web 2013 (detenten 2013) d'Sketch Engine (2020), a part dels contextos esmentats, vam trobar el seu ús també en anuncis d'apartaments compartits en cases (socials) per a persones joves que no poden o volen viure amb els seus familiars i per a persones amb necessitats especials. A més, es troba en anuncis de lloguer de vacances. Per tant, ens sembla que l'ús del lexema Einzelzimmer és molt menys habitual en el cas de lloguer o venta de cases i pisos ordinaris, si bé és possible que els parlants d'algunes varietats diatòpiques ${ }^{26}$ l'utilitzin en aquest context. No obstant això, pensem que el seu ús és poc comú en alemany si no es tracta d'una habitació que es llogui per un període més o menys curt com unes setmanes de vacances.

Trobem problemes amb conceptes inexistents en la cultura alemanya també en l'exemple (24) en el cas de la cèdula d'habitabilitat que il.lustra el problema de traducció de la inexistència d'un concepte en un espai cultural:

(24) cat. la cèdula d'habitabilitat. (HUT)

al. die Bescheinigung der Bewohnbarkeit. (GT)

al. die Bescheinigung über die Bewohnbarkeit (GT)

al. Es muss das Zeugnis der Bewohnbarkeit (BT)

al. das Zertifikat der Bewohnbarkeit. (BT)

La cèdula d'habitabilitat requereix una recerca de conceptes comparables en alemany. Considerant que tant Zertifikat com Bescheinigung o Zeugnis tenen com a (una possible) traducció catalana el certificat, a la fi és la idiomaticitat que ens fa decidir sobre si la solució de la TA és acceptable o no.

Mirem, a més, un exemple més (25) on es pot observar com la TA processa metàfores de maneres variables:

(25) cat. Barcelona és una ciutat que s'ofega entre el mar i la muntanya. limitada per una conurbació que no cedeix un pam d'asfalt. (Vilaweb)

al. Barcelona ist eine Stadt, die zwischen dem Meer und den Bergen ertrinkt. Begrenzt durch einen Ballungsraum, der keinen Pam Asphalt gibt. (BT)

al. Barcelona ist eine Stadt, die zwischen Meer und Bergen ertrinkt. Es wird durch einen Ballungsraum begrenzt, der keine Asphaltpfanne liefert. (GT)

Es tracta, d'una banda, de la metàfora s'ofega entre el mar i la muntanya, que les eines tradueixen literalment, el que resulta en la pèrdua de la idiomaticitat, i el sentit de la qual no queda intacte. Ofegar-se significa 'ersticken' i solament en el cas especial de ofegar-se a l'aigua s'utilizaria 'ertrinken'. En aquest cas, ambdós serveis distorsionen el sentit de la metàfora ja que l'idea que es vol expressar és que la ciutat ha crescut de tal manera que ja no queda espai ni per respirar, ni per estendre's. Tampoc la segona metàfora de l'exemple pam d'asfalt dona un resultat correcte: la TA no arriba a resoldre la metàfora de forma acceptable. GT la tradueix literalment de manera que ni la idiomaticitat ni el sentit (Asphaltpfanne) queden intactes. BT no arriba ni a traduir pam, paraula inexistent en alemany. ${ }^{27}$

25 Vegeu també l'apartat sobre anuncis immobiliaris de Fandrych i Thurmair (2011: 239-249). Els autors no parlen mai d'Einzelzimmer o Doppelzimmer.

26 Agraïm a l'avaluador desconegut que ens va indicar aquest ús en la seva varietat d'alemany.

27 Vegeu per al problema d'idiomaticitat també els resultats de l'estudi que Schmidhofer i Mair (2018: 175-176)

van fer amb estudiants de traducció d'anglès basant-se en els resultats de DeepL. 


\subsection{Contradiccions i errors desapercebuts}

Ja hem indicat a 5.2. i 5.3. que les eines de TA distorsionen diferents vegades el sentit dels textos de partida. La inversió del sentit o la contradicció entre l'original i la TA és un fenomen que ocorre sense que la investigació en tecnologia lingüística hi hagi trobat una explicació. L'exemple (26) mostra l'anomenada ocurrència de manera explícita. L'original iguals o inferiors a 31 dies assumeix un període que compta amb un límit màxim de 31 dies. Però en alemany, la paraula mindestens torna el sentit al límit mínim de 31 dies, és a dir a 31 dies o més.

(26) cat. ... per períodes de temps iguals o inferiors a 31 dies. (HUT).

al. $\quad$... für Zeiträume von mindestens 31 Tagen angeboten wird. (BT)

També trobem aquest fenomen quan els textos de partida són defectius, és a dir, que mostren algun tipus d'error, desapercebut pels preeditors i l'eina, que a vegades porta a resultats fins i tot divertits com en l'últim exemple (27) on es troba una forma distorsionada d'almenys escrita amb e intercalada que GT no va reconèixer com adverbi sinó com nom gentilici: (els) alemanys.

(27) cat. La pèrdua de negocis històrics, la procedència dels nous habitants dels barris o el canvi generacional no s'emmarquen en el fenomen de la gentrificació -o alemenys no només-, sinó en la globalització i el lliure mercat. (Vilaweb)

al. Der Verlust des historischen Geschäfts, die Herkunft der neuen Bewohner der Stadtteile oder der Generationenwechsel passen nicht nur in das Phänomen der Gentrifizierung - oder nicht nur in die Deutschen-, sondern auch in die Globalisierung und den freien Markt. (GT)

Es tracta d'un tipus d'error molt subliminal ja que requereix l'atenció exhaustiva en la PE per trobar-lo. La falta de sentit és evident, però com que al mateix temps la frase en qüestió pot integrar-se en construccions correctes i intel-ligibles com en el cas (26) -una característica positiva de la TA neuronal- aquests errors s'escapen fàcilment del personal editor.

\section{Conclusió}

Tres preguntes van dirigir la nostra anàlisi:

(1) Quins problemes sorgeixen de la TA del català a l'alemany?

(2) Són aquests problemes els mateixos que aquells que també trobem en altres llengües?

(3) Quines dificultats s'han d'atribuir a la combinació de les llengües i quines al tipus de text?

En l'apartat 5 hem abordat detalladament la primera pregunta. Tots els exemples exposen, evidentment, que la qualitat de la TA per a la combinació català-alemany encara no és tan bona i no convenç sense reserves, com podrien pensar estudiants principiants de traducció o persones usuàries ordinàries llegint els articles de Himmelein (2019) o Holzki (2020). Els sistemes més recents de la TA — com el neuronal— produeixen resultats (encara) ambivalents, tant de bona com de mala qualitat alhora, i és imprescindible abans del seu ús en la formació de traductors sensibilitzar l'estudiantat amb els errors i dèficits subliminals que s'amaguen dins d'una TA intel-ligible a primera vista. En el cas de llengües menors, com el del català, és encara més important sensibilitzar-los-en, ja que les eines de TAPE disponibles en el mercat no són tan nombroses i els corpus textuals disponibles són més diversos i més petits. A més, la qualitat de les traduccions, com en el cas de Google i Bing per a la combinació català-alemany, potser no compleix amb les expectatives i exigències de les persones usuàries, com acabem de mostrar. Tanmateix, reconèixer problemes i adonar-se de traduccions deficients importa igualment per al grup d'estudiants de llengua catalana a dintre de la formació filològica perquè aprenguin a avaluar els resultats de la TA. 
El que destaca és la similitud dels problemes identificats pel nostre estudiantat amb aquelles troballes a la TA d'altres combinacions de llengües, fet que van confirmar els nostres col-legues d'altres llengües com l'anglès, el francès i el rus. Encara que en el present article ens dediquem més als aspectes formals i estilístics que altres estudis - la qual cosa es deu, possiblement, que els estudiants els van trobar fàcilment - els aspectes accentuats ja es van esmentar en altres articles, si bé no tenen exactament la mateixa forma. A fi de visualitzar clarament la conformitat dels nostres resultats d'estudis previs, oferim una comparació - sense pretendre ésser exhaustiva respecte dels estudis mencionats- en la taula (2).

Tant entre les llengües català-alemany com entre els modes diferents (traducció humana vs. TA) es poden observar els mateixos reptes que van descriure altres científics per a altres parells de llengües. Schmidhofer i Mair (2018), per exemple, van realitzar un estudi basat en les experiències de dos grups d'estudiants, un traduint de forma manual i l'altre treballant amb la TA. En aquest estudi han identificat categories problemàtiques en tots dos modes de la combinació anglès-alemany. D'una manera general, els resultats coincideixen amb els resultats que vam presentar en l'apartat 5 per a la llengua catalana i l'alemanya. Com hem indicat al llarg de l'article, també altres estudis com Wu et al. (2016) o Łopuszańska (2019) han assenyalat els mateixos problemes. La comparació entre els diferents articles mostra que els diversos aspectes - o almenys una bona part - no es deuen a la combinació de llengües, el català i l'alemany, sinó que presenten, més aviat, fenòmens generals, com els temes de les convencions textuals i culturals, els problemes amb frases llargues i construccions sintàcticament complexes, diversos aspectes relacionats amb la terminologia i el lèxic (p. ex. la traducció erràtica de paraules (de baixa freqüència), la (manca o excés de) variació o les inconsistències terminològiques). No obstant això, la majoria de tals estudis es van realitzar a fi de millorar sistemes de TA i no tenen un propòsit didàctic com el nostre estudi.

\begin{tabular}{|c|c|c|c|c|c|}
\hline $\begin{array}{l}\text { Present estudi } \\
\text { (Paasch-Kaiser/ } \\
\text { Hoberg) } \\
\text { català } \rightarrow \text { alemany }\end{array}$ & $\begin{array}{l}\text { Toral (2019) } \\
\text { anglès } \leftrightarrow \text { alemany, } \\
\text { anglès } \rightarrow \text { francès, } \\
\text { castellà } \rightarrow \text { alemany } \\
\text { xinès } \rightarrow \text { anglès }\end{array}$ & $\begin{array}{l}\text { Koehn / } \\
\text { Knowles (2017) } \\
\text { anglès } \rightarrow \text { castellà, } \\
\text { alemany } \rightarrow \text { anglès }\end{array}$ & $\begin{array}{l}\text { Forcada et al. } \\
(2017) \\
\text { txec } \rightarrow \text { anglès }\end{array}$ & $\begin{array}{l}\text { Schmidhofer i } \\
\text { Mair (2018) } \\
\text { anglès-alemany }\end{array}$ & $\begin{array}{l}\text { Popović (2018) } \\
\text { alemany } \leftrightarrow \text { anglès } \\
\text { anglès } \rightarrow \text { serbi }\end{array}$ \\
\hline \multicolumn{6}{|c|}{ Aspectes formals i estilístics } \\
\hline 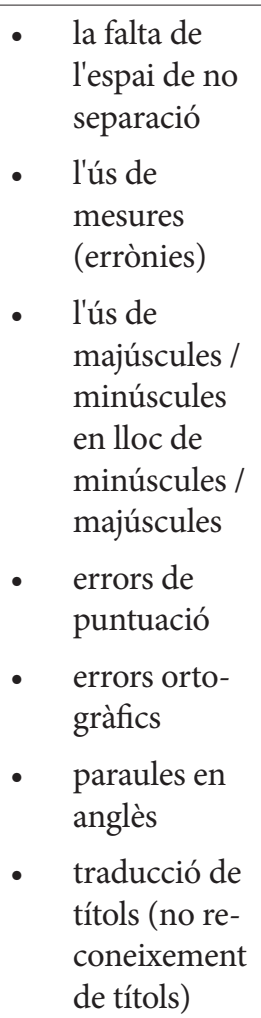 & & & $\begin{array}{l}\text { posiciona- } \\
\text { ment erràtic } \\
\text { d'etiquetes } \\
\text { en la traduc- } \\
\text { ció assistida } \\
\text { per ordina- } \\
\text { dor ("mis- } \\
\text { placing of } \\
\text { formatting } \\
\text { tags") }\end{array}$ & $\begin{array}{ll}\text { - la TA ignora } \\
\text { les con- } \\
\text { vencions } \\
\text { de com } \\
\text { adreçar-se a } \\
\text { les persones } \\
\text { en la cultura } \\
\text { d'arribada } \\
\text { (ús d'impe- } \\
\text { ratiu vs. ús } \\
\text { de formes } \\
\text { directes) }\end{array}$ & \\
\hline
\end{tabular}




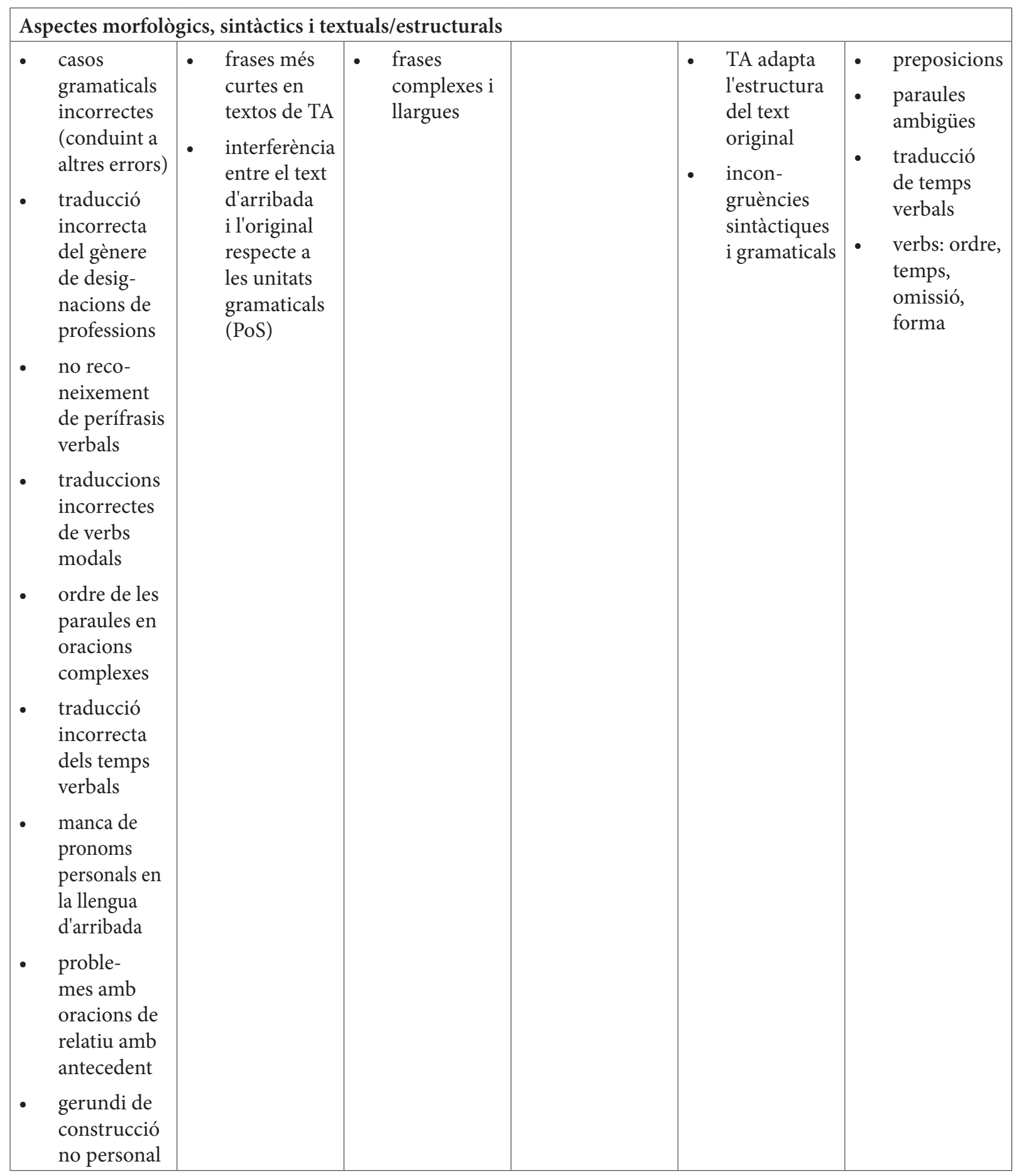

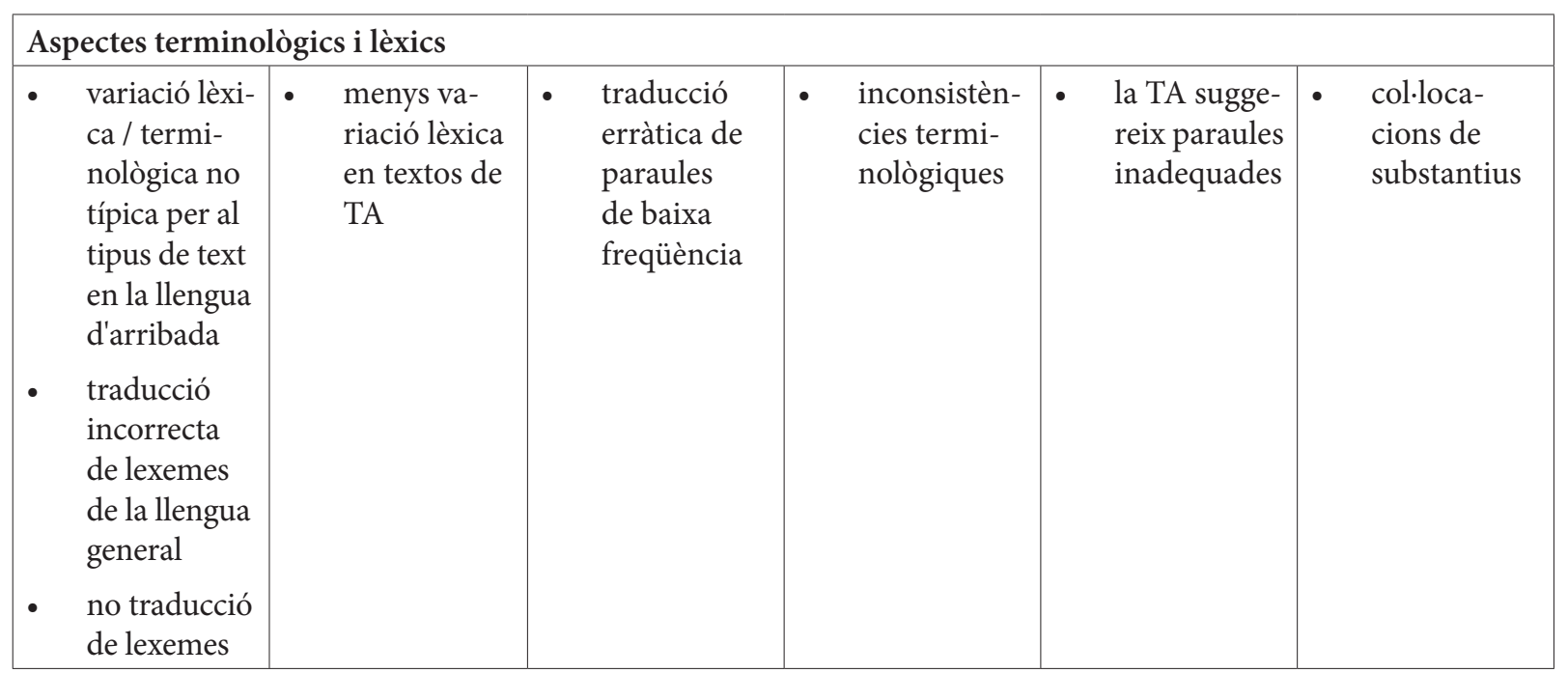




\begin{tabular}{|c|c|c|c|}
\hline \multicolumn{4}{|c|}{ Traducció de topònims } \\
\hline $\begin{array}{l}\text { traducció de } \\
\text { topònims, } \\
\text { a vegades a } \\
\text { l'anglès }\end{array}$ & & $\begin{array}{l}\text { traducció } \\
\text { incorrecta } \\
\text { de composi- } \\
\text { cions }\end{array}$ & \\
\hline \multicolumn{4}{|c|}{ Traducció de terminologia específica } \\
\hline $\begin{array}{l}\text { manca } \\
\text { d'informació } \\
\text { addicional } \\
\text { necessària } \\
\text { per a la } \\
\text { clientela } \\
\text { estrangera }\end{array}$ & $\begin{array}{l}\text { categoria } \\
\text { incorrecta } \\
\text { (“domain } \\
\text { mismatch") }\end{array}$ & & \\
\hline \multicolumn{4}{|c|}{ Contradiccions desapercebudes } \\
\hline & & & $\begin{array}{ll}\text { - } & \text { negació } \\
\text { d'oracions } \\
\text { afirmatives } \\
\text { en el text de } \\
\text { partida } \\
\text { - inversió de } \\
\text { l'enunciat }\end{array}$ \\
\hline \multicolumn{4}{|c|}{ Errors en el text de partida desapercebuts } \\
\hline
\end{tabular}

Taula 2: Comparació dels problemes i errors de la TA del català a l'alemany amb els resultats d'estudis previs.

D'altra banda, la base textual que vam estudiar és massa petita per treure conclusions generalitzables per a la parella de llengües estudiades aquí. Haurien de realitzar-se estudis amb corpus més grans per poder confirmar la hipòtesi que hi ha fenòmens que són particulars de la combinació català-alemany. ${ }^{28}$ A més, s'haurien de comparar els resultats amb aquells d'estudis similars amb les altres llengües iberoromàniques i l'alemany, ja que hi podria haver traduccions similars.

Resulta interessant que respecte als errors que comet l'estudiantat en la traducció humana i els que comet la TA existeixen algunes categories comunes que cal tenir en compte a l'hora d'utilitzar les eines de TA a classe: el tractament d'estructures impersonals i el processament dels requisits formals del text, encara que aquest últim es millora molt ràpidament amb l'experiència de l'estudiantat. Per poder detectar les deficiències de la TA cal fer una bona formació mitjançant un treball meticulós dels textos produïts per les eines de TA, sense negligir, sobretot al principi, el desenvolupament d'altres competències necessàries tant per a la traducció humana com per a la PE (vegeu 5.1).

Quant a la segona part de la pregunta (3), seria perillós i precipitat induir dels nostres resultats (que deriven de l'anàlisi de pocs textos treballats a classe) unes conclusions generals per a un dels tipus de text examinat. És més aviat necessari dur a terme altres estudis dedicats només a un dels tipus o textos estudiats, $\mathrm{o}$ a una quantitat major de textos dels diferents tipus

28 En els últims anys, ha crescut el nombre d'estudis sobre la TA cap a llengües de pocs recursos, p. ex. Costa-Jussà (2017) que enfoca la TA de castellà al català o de do Campo Bayón i Sánchez-Gijón (2019), que ofereix un estat de investigació respecte a la TA per al gallec. Estudis similars també es realitzen, actualment, per a altres combinacions de llengües, com mostra l'estudi de Przystupa i Abdul-Mageed (2019) sobre TA del castellà al portuguès i a la inversa, del txec al polonès i a la inversa, així com de l'hindi cap al nepalès i a la inversa. 
de text. No obstant això, el nostre estudi presenta un bon punt de partida cridant l'atenció a l'estudi de les eines de TA entre una llengua menor i una major.

No hi ha dubte que capacitar l'estudiantat en el manejament de la TAPE és un dels punts més vitals de la formació actual, prenent en compte les exigències del mercat laboral entre les quals figura aquesta competència. A través de programaris lliures i de propietat, disponibles i accessibles gratuïtament $\mathrm{o}$ a preus econòmics en l'àmbit de la universitat, els estudiants poden accedir als sistemes de la TAPE per fer-se una idea del seu funcionament, de les seves diferències i de les anomenades exigències del mercat laboral. L'accés a serveis en línia també facilita l'educació universitària de traducció. La integració i la confrontació profundes amb la TAPE en la formació universitària de traductors des de diferents perspectives és, d'avui endavant, absolutament necessària per a una preparació integral de l'estudiantat, si bé la nostra pròpia experiència amb les eines de TA Google Translate i Bing mostra que la integració d'aquesta (ja no tant) nova branca de l'ofici de la traducció planteja reptes i obstacles, no solament per a l'estudiantat sinó també per al professorat.

Considerem, per últim, la retroacció dels nostres estudiants respecte al concepte del curs integral. Tot i que a primera vista sembla com si tot l'esforç d'integrar la TAPE només resultés en un treball innecessari, tenint en compte que els resultats de la TA són sovint defectuosos i que la fase preparativa dels textos encara els demana molt de temps, els estudiants van avaluar tant l'alternança de traducció humana i TA del mateix text com el curs, en general, de manera positiva. Van remarcar que l'ús de les tecnologies de TAPE no solament representa una oferta addicional dins del currículum dels estudis, sinó que aporta un valor suplementari i professional a la formació, ja que fins aquest moment només és integrat en pocs cursos d'una manera fixa.

Conseqüentment, d'una banda, el grup estava d'acord amb els docents en què capacitar els futurs traductors per a l'ús de tecnologies digitals requereix molt de temps. D'altra banda, la integració de l'ús de tecnologies digitals representa exactament les demandes del mercat de treball; com ja hem destacat al principi de l'article, la xifra dels encàrrecs en què la TAPE és el nucli del processament està creixent.

\section{Referències bibliogràfiques}

Bernaus Griñó, O. \& C. Sinner (2016): "La traducció com a eina d'aprenentatge d'una L2", en: N. Camps; M. Casas; Ll. Comajoan \& T. Puntí (ed.): L'ensenyament del català als territoris de parla catalana. Estat de la qüestió i perspectives de futur. Universitat de Vic / Universitat Central de Catalunya, 203-208.

Blaschke, M. (2018): "Lehrveranstaltungen katalanischer Thematik an den Hochschulen des deutschen Sprachbereichs im Sommersemester 2017 und im Wintersemester 2017/2018”. Zeitschrift für Katalanistik 31, 351-360.

Bowker, L. \& J. Buitrago Ciro (2015): "Investigating the usefulness of machine translation for new-comers at the public library." Translation and Interpreting Studies 10, 2, 165-186.

Costa-jussà, M. R. (2017): "Why Catalan-Spanish Neural Machine Translation? Analysis, comparison and combination with standard Rule and Phrase-based technologies." En: Association for Computational Linguistics (ed.): Proceedings of the Fourth Workshop on NLP for Similar Languages, Varieties and Dialects (Valencia, Spain, April 3, 2017), 55-62.

Čulo, O. \& J. Nitzke (2016): "Patterns of terminological variation in post-editing and of cognate usein machine translation in contrast to human translation." En: Proceedings of the 19th Annual Conference of the European Association for Machine Translation, EAMT 2017, Riga, Latvia, May 30-June 1, 2016, <https://www.aclweb.org/anthology/W16-3401>, 106-114.

Čulo, O.; S. Hansen-Schirra \& J. Nitzke (2017): “6 Contrasting terminological variation in post-editing and human translation of texts from the technical and medical domain.” En: G. 
De Sutter / M.A. Lefer / I. Delaere (eds.): Empirical Translation Studies. Berlin: De Gruyter Mouton. 183-206, <https://doi.org/10.1515/9783110459586-007>.

CRACKER $(2020 \mathrm{a})=<$ http://cracker-project.eu/> (consulta: 25/2/2020).

CRACKER (2020b) = <http://cracker-project.eu/wp-content/uploads/SRIA-V1.0-final.pdf > (consulta: 25/2/2020).

Daems, J.; O. De Clercq \& L. Macken (2017): “Translationese and post-editese: how comparable is comparable quality?” Linguistica Antverpiensia New Series-Themes In Translation Studies, 16, <https://lans-tts.uantwerpen.be/index.php/LANS-TTS/article/view/434>, 89-103.

DIN (2020) = DIN 5008 „Schreib- und Gestaltungsregeln für die Textverarbeitung“, $<$ https://www.din-5008-richtlinien.de/> (consulta: 25/2/2020).

DicCat $(2020)=<$ www.diccionari.cat $>$ (consulta: 27/2/2020).

do Campo Bayón, M. \& P. Sánchez-Gijón (2019): "Evaluating machine translation in a low-resource language combination: Spanish-Galician.” En: Proceedings of MT Summit XVII, Dublin, August 19-23, 2019, vol. 2: Translator, Project and User Tracks, <https://fc233576-d4db4de9-b637-e339437e9442.filesusr.com/ugd/705d57_b3899f00d8f348299c2915186221bab2. pdf $>, 30-35$.

Duden (2009) = Dudenredaktion (eds.): Die Grammatik. Unentbehrlich für richtiges Deutsch. 8., überarbeitete Auflage. Dudenverlag. [Duden Band 4].

Duden (2020) $=<$ www.duden.de/sprachwissen/rechtschreibregeln $>$ (consulta: 25/2/2020).

Elsen, H. (2012): “Maschinelle Übersetzung - Postediting - Schreckgespenst oder Perspektive?” MDÜ - Fachzeitschrift für Dolmetscher und Übersetzer 4, 16-17.

Fandrych, C. \& M. Thurmair (2011): Textsorten im Deutschen. Linguistische Analysen aus sprachdidaktischer Sicht. Stauffenburg Verlag.

Farrell, M. (2018): "Machine Translation Markers in Post-Edited Machine Translation Output." En: AsLing, The International Association for Advancement in Language Technology (eds.) Proceedings of the 40th Conference Translating and the Computer, London, November 15-16, 2018. Editions Tradulex, 50-59.

Farrús, M.; M. R. Costa-Jussà; M. Poch; A. Hernández \& J. B. Mariño (2009): "Improving a Catalan-Spanish Statistical Translation System Using Morphosyntactic Knowledge". Proceedings of the 13th Annual Conference of the European Association for Machine Translation. European Association for Machine Translation, 52-57.

Farrús, M.; M. R. Costa-Jussà; J. B. Mariño \& J. A. R. Fonollosa (2010): "Linguistic-Based Evaluation Criteria to Identify Statistical Machine Translation Errors". 14th Annual Conference of the European Association for Machine Translation. European Association for Machine Translation, 167-173.

Forcada, M. L. (2017): "Making Sense of Neural Machine Translation". Translation Spaces 6, 2, 291-309. <https://doi.org/10.1075/ts.6.2.06for> (consulta: 3/9/2020).

Forcada, M. L.; C. Scarton; L.Specia; B. Haddow \& A. Birch (2018). "Exploring Gap Filling as a Cheaper Alternative to Reading Comprehension Questionnaires when Evaluating Machine Translation for Gisting". CoRR abs/1809.00315. <http://arxiv.org/abs/1809.00315> (consulta: 3/9/2020).

GenCat (2020a) = Generalitat de Catalunya (2020): “Traducció automàtica", <https://llengua. gencat.cat/ca/eines_i_serveis/traduccio-automatica-en-linia/> (consulta: 28/2/2020). 
GenCat $(2020 b)=$ Generalitat de Catalunya (2020): <https://lengua.gencat.cat/ca/detalls/ noticia/La-Direccio-General-de-Politica-Lingueistica-impulsa-el-catala-en-lambit-digital> (consulta: 12/2/20).

GenCat $(2020 \mathrm{c})=$ Generalitat de Catalunya (2020): <https://llengua.gencat.cat $/ \mathrm{ca} / \mathrm{ser}-$ veis/06_catala_llengua_digital/> (consulta: 12/2/20).

Grizzo, S. (2017): “Das Post-Editing in der Praxis". Presentació a la trobada anual tekom-Jahrestagung, Stuttgart.

Grizzo, S. (2019): “Da geht noch mehr - Übersetzen in der digitalen Welt“, MDÜ - Fachzeitschrift für Dolmetscher und Übersetzer, 1, 14-19.

Himmelein, G. (2019): “Die smarte Wortfabrik”. c't 25, 138-145.

Holzki, L. (2020): “Digitale Revolution: Das Ende der Sprachgrenzen - wenn der Algorithmus alles übersetzt", en: <https://www.handelsblatt.com/technik/digitale-revolution/digitale-revolution-das-ende-der-sprachgrenzen-wenn-der-algorithmus-alles-uebersetzt/25480752.

html> (consulta: 2/10/2020).

Institut Ramon Llull (2020): “Universitats de l'exterior amb docència d'estudis catalans - Curs acadèmic 2019-2020 àrea de llengua i universitats", <https://www.llull.cat/rec_docs_2019/ mapa_web.pdf> (consulta: 4/2/2020).

Koehn, P.; R. Knowles (2017): "Six Challenges for Neural Machine Translation". arXiv:1706.03872 [cs], <http://arxiv.org/abs/1706.03872>.

Kupsch-Losereit, S. (2009): "Die kulturelle Kompetenz des Translators", Lebende Sprachen, 47(3), 97-101, <https://doi.org/10.1515/les.2002.47.3.97>.

Łopuszańska, G. (2019): “Maschinelle Übersetzung - Grenzen und Möglichkeiten”, Linguistische Treffen in Wrocław 15, I. 145-156, <https://doi.org/10.23817/lingtreff.15-12>.

Macken, L.; D. Prou; A. Tezcan (2020): "Quantifying the Effect of Machine Translation in a High-Quality Human Translation Production Process”. Informatics 2020, 7, 12, <https://doi. org/10.3390/informatics7020012>.

Markstein, E. (1999): “Realia”. En Snell-Hornby, M. et al. (eds.): Handbuch Translation. Zweite, verbesserte Auflage. Stauffenburg, 288-291.

Massardo, I.; J. van der Meer; S. O'Brien; F. Hollowood; N. Aranberri; K. Drescher (2016): MT Post-Editing Guidelines. TAUS Signature Editions.

Microsoft (2016): "Microsoft Research Blog": Microsoft NLP researchers converge at ACL 2016, edging ever closer to human-like conversational experiences", <https://www.microsoft. com/en-us/research/blog/microsoft-nlp-researchers-converge-acl-2016-edging-ever-closer-human-like-conversational-experiences/> (consulta: 10/8/2020).

Plataforma $(2019)$ = "Catalan language \& internet: key facts", <https://www.plataforma-llengua.cat/media/upload/pdf/pl_internet-eng-2-fulleto-catala-internet-sense-marques_1549535432.pdf> (consulta: 12/2/2020).

Popović, M. (2018): "Language-Related Issues for NMT and PBMT for English-German and English-Serbian". Machine Translation 32, 3, 237-253,

$<$ https://doi.org/10.1007/s10590-018-9219-5>.

Przystupa, M. \& M. Abdul-Mageed (2019): "Neural Machine Translation of Low-Resource and Similar Languages with Backtranslation." En: Association for Computational Linguistics (eds.): Proceedings of the Fourth Conference on Machine Translation (WMT), Vol. 3: Shared Task Papers (Day 2), Florence, Italy, August 1-2, 2019, 224-235, $<$ https://doi.org/10.18653/v1/W19-5431>. 
QT 21 (2020) = QT21 Consortium (2020): QT21 - Quality Translation 21, <http://www.qt21. eu/resources/data/>, accés: 25/2/2020.

Schmidhofer, A. \& N. Mair (2018): "Machine Translation in Translator Education / La traducción automática en la formación de traductores" CLINA 4, 2, 163-180, <https://doi. org/10.14201/clina201842163180>.

Schmitt, P. A. (2019): “Translation 4.0 - Evolution, Revolution, Innovation or Disruption?”, Lebende Sprachen 64, 2, 193-229, <https://doi.org/10.1515/les-2019-0013>.

Sinner, C. (2017): “Sprachmittlung im universitären Übersetzungsunterricht”. Hispanorama $155,4-10$.

Sinner, C. \& C. Bahr (2015): "Reflexionen über didaktische Materialien zur Sprachmittlung im Fremdsprachenunterricht. Das Beispiel von 'Kommunikativ stark - Sprachmittlung Spanisch' (Schöpp/Rojas Riether 2014)”. Hispanorama 150, 77-85.

Sinner, C.; C. Paasch-Kaiser \& J. Härtel (2020a): Translation in the Digital Age: Translation 4.0. Newcastle upon Tyne: Cambridge Scholar Publishing.

Sinner, C.; C. Paasch-Kaiser \& J. Härtel (2020b): Translation 4.0 - Dolmetschen und Übersetzen im Zeitalter der Digitalisierung. Peter Lang.

Sinner, C. \& K. Wieland (2013): "Eine translationswissenschaftliche Sicht auf Sprachmittlung im Fremdsprachenunterricht”, en: D. Reimann; A. Rössler (eds.) (2013): Sprachmittlung im Fremdsprachenunterricht. Tübingen: Narr, 93-113.

Sketch Engine (2020) = <https://www.sketchengine.eu > consulta: 10/7/2020).

Torral, A. (2019): “Post-editese: an Exacerbated Translationese”. En: M. Forcada; A. Way; B. Haddow \& R. Sennrich (ed.): Proceedings of Machine Translation Summit XVII. Volume 1: Research Track. Dublin, Aug. 19-23, 2019, 273-281.

UNIVERSITAS 2020 = S. V. (2020): “Übersetzen und Dolmetschen 4.0 Neue Wege im Digitalen Zeitalter' BDÜ-Konferenz, 22.-24.11.2019”. Universitas Mitteilungsheft 1, 13-24.

Wu, Y.; M. Schuster; Z. Chen; Q. V. Le; M. Norouzi; W. Macherey; M. Krikun; Y. Cao; Q. Gao; K. Macherey; J. Klingner; A. Shah; M. Johnson; X. Liu; Ł. Kaiser; S.Gouws; Y. Kato; T. Kudo; H. Kazawa; K. Stevens; G. Kurian; N. Patil; W. Wang; C. Young; J. Smith; J. Riesa; A. Rudnick; O. Vinyals; G. Corrado; M. Hughes; J. Dean (2016): "Google's Neural Machine Translation System: Bridging the Gap between Human and Machine Translation". arXiv:1609.08144v2 [cs.CL], <https://arxiv.org/abs/1609.08144v2>, 1-23 (consulta: 12/2/2020).

Zetzsche, J. (2016): “A new kid in town - CAT-Tool Lilt". MDÜ - Fachzeitschrift für Dolmetscher und Übersetzer 62, 38-41. 